\title{
The in vivo effects of beta-3-receptor agonist CGP-12177 on thyroxine deiodination in cold-exposed, sympathectomized rat brown fat
}

\author{
Dietmar Hofer ${ }^{1}$, Marcela Raíces ${ }^{4}$, Konrad Schauenstein ${ }^{2}$, Sepp Porta ${ }^{2}$, Wolfgang Korsatko ${ }^{3}$, Karl Hagmüller ${ }^{1}$ \\ and Angel Zaninovich ${ }^{4}$ \\ Departments of ${ }^{1}$ Zoology, ${ }^{2}$ Pathophysiology and ${ }^{3}$ Pharmaceutical Chemistry, University of Graz, Austria and ${ }^{4}$ Hospital de Clínicas and Ingebi, \\ University of Buenos Aires, Argentina \\ (Correspondence should be addressed to A Zaninovich, Hospital de Clínicas, C.C. 29 Ofic.Facultad, 1453 Buenos Aires, Argentina; Email: \\ azaninovich@sinectis.com.ar)
}

\begin{abstract}
Objective: The effects of the beta-3-receptor agonist CGP-12177 on thyroxine (T4) deiodination in sympathectomized (SX) interscapular brown adipose tissue (BAT) were assessed in $300 \mathrm{~g}$ body weight (BW) Wistar rats.

Design: Seven days after SX, groups of rats were implanted s.c. with pellets containing $5 \mathrm{mg}$ CGP12177 or $5 \mathrm{mg}$ norepinephrine (NE) and were immediately placed at $4{ }^{\circ} \mathrm{C}$ for $24 \mathrm{~h}$. Other SX groups were injected with CGP-12177 or NE $1 \mathrm{mg} / \mathrm{kg}$ BW i.p. and placed in the cold for $4 \mathrm{~h}$. The latter group was injected, in addition, with prazosin $0.4 \mathrm{mg} / 100 \mathrm{~g} \mathrm{BW}$ i.p. or propranolol $0.5 \mathrm{mg} / 100 \mathrm{~g}$ BW i.p. $15 \mathrm{~min}$ before and $2 \mathrm{~h}$ after the administration of CGP-12177 or NE.

Methods: Two hours after the last injection of prazosin or propranolol, animals were killed and BAT was removed, homogenized and centrifuged at $500 \mathrm{~g}$ for $10 \mathrm{~min}$ at $4^{\circ} \mathrm{C}$. The infranatants were incubated during $60 \mathrm{~min}$ in the presence of dithiothreitol and $1 \mu \mathrm{Ci}\left[{ }^{125} \mathrm{I}\right] \mathrm{T} 4$. Aliquots were chromatographed on paper for the measurement of $\left[{ }^{125} \mathrm{I}\right] \mathrm{T} 4$ and its deiodinated subproducts.

Results: CGP-12177 restored normal T4 deiodination in SX BAT from both groups, but NE was slightly more effective. Propranolol, although not prazosin, blocked the CGP-12177 effects. Contrariwise, the NE-induced rise in deiodination was blocked by prazosin and to a lesser extent by propranolol.

Conclusions: The results indicate that CGP-12177 stimulated the in vivo activation of 5'-deiodinase type II activity predominantly via beta-3-receptor, without participation of alpha-1-receptors.
\end{abstract}

European Journal of Endocrinology 143 273-277

\section{Introduction}

The ability of brown adipose tissue (BAT) to increase thermogenesis in response to cold is largely dependent on the presence of norepinephrine (NE) and the thyroid hormones (1-6). BAT NE is supplied almost totally by the sympathetic nerves, whereas BAT triiodothyronine (T3) is regulated through the activation of $5^{\prime}$-deiodinase type II $\left(5^{\prime}\right.$-DII), which converts thyroxine (T4) to T3 (7). The effects of NE on BAT uncoupling protein (UCP1) synthesis are mediated predominantly via beta-3-receptors (8), whereas alpha-1-receptors (7) and the synergism between alpha-1- and beta-receptors (9) have been reported to mediate the synthesis of $5^{\prime}$-DII.

The selective beta-3-adrenoreceptor agonist CGP12177 activates BAT thermogenesis, as measured by GDP binding to UCP sites, UCP concentration or mitochondrial oxygen consumption $(10,11)$. The effects of this agonist on BAT $5^{\prime}$-DII activity in vivo are less known. In view of the significance of $\mathrm{T} 4$ deiodination in BAT thermogenic activity, the present work set out to investigate the effects of the in vivo administration of CGP-12177 on sympathectomized (SX) BAT 5'-DII activity in response to cold. The effects of $\mathrm{NE}$ and a variety of synthetic agonists or antagonists of adrenergic receptors have long been thoroughly investigated. The present work studied the effects of NE on 5'-DII activity only, for comparison with the effects induced by CGP-12177 under similar experimental conditions.

\section{Materials and methods}

\section{Animals}

Male Wistar rats (Department of Zoology, University of Graz) of approximately $300 \mathrm{~g}$ body weight (BW) were used. Purina rat chow and water were freely available in a room with lights on between 0600 and $2000 \mathrm{~h}$. 


\section{Reagents}

Double-labeled $\left[3^{\prime}, 5^{\prime}-{ }^{125} \mathrm{I}\right] \mathrm{T} 4$ with a specific activity of $1280 \mu \mathrm{Ci} / \mu \mathrm{g}$ was purchased from Amersham International plc, Amersham, Bucks, UK, and was used within a week of arrival. It was $95 \%$ pure and the rest was ${ }^{125} \mathrm{I}$ and traces of $\left[{ }^{125} \mathrm{I}\right] \mathrm{T} 3$. The proportions of these contaminants were determined in duplicate by chromatographic runs in each experiment and were substracted from the results. 1,4-Dithio-L-threitol (DTT), NE bitartrate, prazosin and DL-propranolol were purchased from Sigma Chemical Co., St Louis, MO, USA. The beta-3-receptor agonist CGP-12177 was kindly provided by Novartis, Basel, Switzerland.

\section{Experiment 1}

Groups of rats were subjected to BAT SX or sham operation in the manner described in a previous report (12). After closing the surgical incision, animals were returned to individual cages and maintained at $\sim 24^{\circ} \mathrm{C}$ with food and water freely available for 7 days. On day 8 , sham and SX rats were implanted, s.c., under light ether anesthesia, with pellets containing either $5 \mathrm{mg}$ CGP-12177 or $5 \mathrm{mg}$ NE. Another group of SX rats were implanted with pellets devoid of CGP-12177 or NE, thus serving as SX controls. The pellets were made up of a polysaccharide matrix (Eudragit, Röhm GmbH, Darmstadt, Germany) and the respective adrenergic compound, and were prepared as described elsewhere (13). Immediately thereafter, rats were placed in individual cages in a cold-room at $4^{\circ} \mathrm{C}$, with free access to food and tap water. After $24 \mathrm{~h}$, animals were killed by cervical dislocation, blood and BAT were obtained and BAT was immediately processed as described below.

\section{Experiment 2}

Groups of SX rats were injected with a single dose of either CGP-12177 or NE $1 \mathrm{mg} / \mathrm{kg}$ BW, i.p. Shamoperated rats received the vehicle alone. Animals were immediately placed in individual cages in a cold-room at $4{ }^{\circ} \mathrm{C}$. Fifteen minutes before and $2 \mathrm{~h}$ after the injection of CGP-12177 or NE, rats received prazosin $0.4 \mathrm{mg}$ or propranolol $0.5 \mathrm{mg} / 100 \mathrm{~g} \mathrm{BW}$, i.p. Rats were killed $2 \mathrm{~h}$ after the last injection of prazosin or propranolol. BAT was removed and processed. Five rats per group were studied.

\section{Deiodination studies}

BAT homogenates were prepared as described before (14). Tissue samples were homogenized in ice-cold buffer containing sucrose $(320 \mathrm{mmol} / \mathrm{l})$ and Hepes $(10 \mathrm{mmol} / \mathrm{l})$ in a proportion of $1 \mathrm{~g}$ BAT to $4 \mathrm{ml}$ buffer, $\mathrm{pH}$ 7.4. The mixture was centrifuged at $500 \mathrm{~g}$ for $10 \mathrm{~min}$ at $4^{\circ} \mathrm{C}$. The infranatant $(6.8-9.7 \mathrm{mg}$ protein/ $\mathrm{ml}$ ) contained the deiodinating activity and was used for the study of T4 deiodination. To $200 \mu \mathrm{l}$ aliquots of infranatants were added $10 \mathrm{mmol} / \mathrm{l}$ DTT (final concentration) and $1 \mu \mathrm{Ci}\left[{ }^{125} \mathrm{I}\right] \mathrm{T} 4$ carrying $1 \mathrm{pmol} \mathrm{T} 4$. The final substrate concentration was $5.1 \mathrm{nmol} / \mathrm{l}$. A previous study (14) showed that larger T4 concentrations $(1 \mu \mathrm{mol} / \mathrm{l})$ were needed to inhibit $\mathrm{T} 4$ deiodination under these experimental conditions. Tissue-free tubes containing reagents in concentrations similar to those added to the homogenates, plus labeled T4, were also prepared. All aliquots and blanks were incubated in a water-bath under continuous shaking at $37^{\circ} \mathrm{C}$ for $60 \mathrm{~min}$. The deiodination reaction was stopped by the addition of an equal volume of methanol:ammonia $(99: 1, v / v)$. Aliquots $(20 \mu \mathrm{l})$ of each homogenate and blanks were applied to Whatman 1 paper and chromatographed in a tertiary amyl alcohol:hexane: ammonia (10:1:12, v/v) system together with the appropriate non-radioactive carriers for approximately $18 \mathrm{~h}$. Chromatograms were cut into $0.5 \mathrm{~cm}$ segments and ${ }^{125} \mathrm{I}$ in them counted. The resulting histograms allowed a clear identification of the radioactive compounds, which were correlated with the stained areas in duplicate strips. Radioactivity in the chromatograms were corrected for the proportion of each radioactive compound other than $\left[{ }^{125} \mathrm{I}\right] \mathrm{T} 4$ present in the chromatographic runs of the standard solutions as received from the commercial source and of blanks incubated concomitantly with the homogenates. This chromatographic technique allowed a reliable assessment of the percentage distribution of the radioactive compounds generated during the incubation of labeled $\mathrm{T} 4(15,16)$. The absolute amount of $\left[{ }^{125} \mathrm{I}\right] \mathrm{T} 4$ deiodinated during the incubation period was derived from knowing the percentage of $\left[{ }^{125} \mathrm{I}\right] \mathrm{T} 4$ present in the homogenates and the amount of added T4. The values were expressed in $\mathrm{pg} / \mathrm{mg}$ of $\mathrm{protein} / \mathrm{h}$.

\section{NE measurement}

BAT NE was measured by techniques described elsewhere (17). Briefly, BAT was homogenized at $4{ }^{\circ} \mathrm{C}$ in perchloric acid, EDTA and ascorbic acid and centrifuged for $10 \mathrm{~min}$ at $24000 \mathrm{~g}$. Supernatants were treated with ammonium chloride, EDTA and a diphenylborate-ethanolamine complex, and also with octanol-heptane and a tetraoctylamino-bromide complex. After 5 min stirring and 5 min centrifugation the supernatant was resuspended in octanol, extracted with acetic acid and injected into an HPLC apparatus for the analysis of catecholamines using Beckman System Gold software (Fullerton, CA, USA) and a BAS-LG-4B electrochemical detector (Biolab, Vienna, Austria). The limit of detection was $50 \mathrm{pg}$ NE/ml. Results are expressed as $\mathrm{pg} / \mathrm{mg}$ wet tissue.

\section{Other methods}

Statistical analyses were performed by ANOVA and Duncan's test. 
Table 1 BAT weight, protein and NE contents after a $24 \mathrm{~h}$ cold exposure. Means \pm S.D. BAT NE was measured in separate groups of similarly treated rats. Numbers in parentheses indicate number of rats. Pellets containing $5 \mathrm{mg} \mathrm{CGP-12177}$ or NE were implanted s.c. immediately before animals were placed in a cold-room.

\begin{tabular}{lcccc}
\hline Groups & $\begin{array}{c}\text { Body weight } \\
(\mathrm{g})\end{array}$ & $\begin{array}{c}\text { BAT weight } \\
(\mathrm{mg})\end{array}$ & $\begin{array}{c}\text { BAT protein } \\
(\mathrm{mg} / \mathrm{ml})\end{array}$ & $\begin{array}{c}\text { BAT NE } \\
(\mathrm{pg} / \mathrm{mg} \text { tissue })\end{array}$ \\
\hline Sham (8) & $310 \pm 28$ & $288 \pm 33^{\mathrm{a}}$ & $10.8 \pm 1.2^{\mathrm{a}}$ & $676 \pm 85^{\mathrm{d}}$ \\
SX (8) & $328 \pm 22$ & $221 \pm 43^{\mathrm{c}}$ & $7.6 \pm 0.8^{\mathrm{b}}$ & $90 \pm 27^{\mathrm{e}}$ \\
CGP-12177 (7) & $315 \pm 28$ & $238 \pm 32$ & $8.6 \pm 1.1^{\mathrm{c}}$ & - \\
NE (7) & $296 \pm 25$ & $266 \pm 32$ & $8.6 \pm 1.1^{\mathrm{c}}$ & $299 \pm 31^{\mathrm{e}}$ \\
\hline
\end{tabular}

$P$ values in each column: ${ }^{a}$ versus ${ }^{b}<0.01 ;{ }^{a}$ versus ${ }^{c}<0.05 ;{ }^{d}$ versus ${ }^{e}<0.01$ (ANOVA).

\section{Results}

Results of BAT weight, protein and NE concentrations after $24 \mathrm{~h}$ of cold exposure are shown in Table 1 . BAT denervation induced a significant decrease in total proteins $(P<0.01$ versus sham group), and this effect was unchanged by the injection of CGP-12177 or NE. Seven days after SX, BAT NE declined to the limits of detection $(P<0.01)$. The values increased markedly after the implantation of NE pellets but reached only one-half the concentration of NE seen in normal BAT. BAT concentration of CGP-12177 could not be determined. The distribution of deiodinated T4 among its metabolic subproducts in rats treated with receptor blockers is seen in Table 2. The results show that more than $97 \%$ of deiodinated T4 was apportioned almost equally between T3 and iodide, the rest being traces of T2. Comparable percentages of $\mathrm{T} 3$ and iodide production were observed in rats implanted with pellets (data not shown). Figure 1 shows the absolute $\mathrm{T} 4$ deiodinated in rats subjected to sham or SX operations. Denervation sharply reduced deiodination $(P<0.01)$. Normal deiodination was restored after the implantation of CGP-12177 or NE pellets. Figure 2 depicts the results from the second experiment, performed $4 \mathrm{~h}$ after the injection of the adrenergic agonists. Both CGP-12177 and NE restored normal T4 deiodination in SX rats. Although the study was terminated at $4 \mathrm{~h}$, it is possible that the stimulatory action of CGP-12177 may have lasted longer, similar to the effects of NE seen in earlier studies (18). The effects of CGP-12177 were abolished by propranolol $(P<0.01)$ whereas prazosin failed to induce significant changes. Because BAT from SX rats was devoid of NE, the results indicate that propranolol had blocked predominantly or solely the action of CGP-12177. Conversely, prazosin was effective in blocking the stimulatory activity of NE $(P<0.01)$, as shown in earlier studies of Silva \& Larsen. $(7,18)$. However, propranolol also impaired the response to NE $(P<0.05)$, an effect not seen in those reports.

\section{Discussion}

Activation of BAT thermogenesis involves the binding of NE to BAT beta-3-adrenergic receptors, followed by the stimulation of adenylate cyclase (5). Different subtypes of beta-receptors have tissue selectivity, e.g. beta-1 in heart, beta- 2 in lung and beta- 3 in adipose tissue. However, all three beta-receptors coexist in BAT (19, 20). It is also clear that BAT expresses the genes of the three beta-receptors and that each receptor mediates a

Table $2 \mathrm{~T} 4$ deiodination and its subproducts as \% of added $\left[{ }^{125} \mathrm{I}\right] \mathrm{T} 4 \mathrm{in}$ rats studied $4 \mathrm{~h}$ after the injection of the adrenergic agonists. Means \pm S.D. Sham and SX rats were injected with CGP-12177 or NE $1 \mathrm{mg} / \mathrm{kg} \mathrm{BW}$, i.p. and placed in a cold-room at $4{ }^{\circ} \mathrm{C}$. Prazosin and propranolol were injected $15 \mathrm{~min}$ before and $2 \mathrm{~h}$ after the administration of the respective adrenergic agonist. Animals were killed $2 \mathrm{~h}$ after the last injection of the receptor blocker. Five rats per group were studied.

\begin{tabular}{|c|c|c|c|c|}
\hline Groups & $\begin{array}{c}{\left[{ }^{125} \mathrm{I}\right] \mathrm{T4}} \\
\text { deiodinated }\end{array}$ & $\begin{array}{c}{\left[{ }^{125} \mathrm{I}\right] \mathrm{T} 3} \\
\text { produced }\end{array}$ & $\begin{array}{l}{ }^{125} \text { I } \\
\text { produced }\end{array}$ & Others* \\
\hline Sham & $65.2 \pm 7.6^{\mathrm{a}}$ & $32.8 \pm 3.8^{a}$ & $30.8 \pm 2.6^{a}$ & $2.3 \pm 1.9$ \\
\hline SX & $23.0 \pm 3.9^{b}$ & $10.6 \pm 1.8^{b}$ & $11.4 \pm 2.8^{b}$ & $1.4 \pm 1.1$ \\
\hline$S X+C G P-12177$ & $56.3 \pm 5.1^{c}$ & $25.9 \pm 1.8^{C}$ & $28.9 \pm 4.3^{c}$ & $2.1 \pm 1.8$ \\
\hline Prazosin & $47.5 \pm 5.1$ & $22.9 \pm 2.4$ & $23.5 \pm 2.8$ & $0.9 \pm 0.7$ \\
\hline Propranolol & $25.6 \pm 4.4^{d}$ & $13.2 \pm 2.3^{d}$ & $10.8 \pm 1.6^{\mathrm{d}}$ & $2.1 \pm 1.4$ \\
\hline $\mathrm{SX}+\mathrm{NE}$ & $64.1 \pm 7.5^{\mathrm{e}}$ & $30.8 \pm 3.2^{\mathrm{e}}$ & $32.3 \pm 3.5^{\mathrm{e}}$ & $1.8 \pm 1.2$ \\
\hline Prazosin & $28.8 \pm 4.3^{f}$ & $13.7 \pm 2.5^{f}$ & $12.9 \pm 2.1^{f}$ & $1.7 \pm 1.2$ \\
\hline Propranolol & $43.1 \pm 5.9^{g}$ & $20.7 \pm 2.5^{\mathrm{g}}$ & $21.1 \pm 2.4^{\mathrm{g}}$ & $1.5 \pm 1.3$ \\
\hline
\end{tabular}

*Traces of $\left[{ }^{125} \mathrm{I}\right] \mathrm{T} 3,3^{\prime}-\mathrm{T} 2$ and other unidentified substances.

$P$ values: ${ }^{a}$ versus $^{b},{ }^{c}$ versus $^{d}$ and ${ }^{\mathrm{e}}$ versus ${ }^{\mathrm{f}},<0.01$; $^{\mathrm{e}}$ versus $^{\mathrm{g}},<0.02$ (ANOVA). 


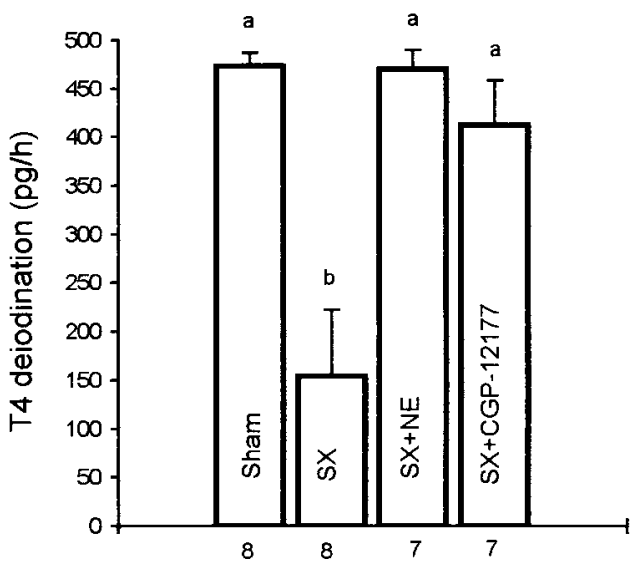

Figure 1 Effects of beta-3-adrenergic agonist CGP-12177 and NE on T4 deiodination in SX BAT. Results are means \pm S.D. Numbers below bars indicate the number of experiments. Animals were implanted s.c. with pellets containing CGP-12177 $5 \mathrm{mg}$ or NE $5 \mathrm{mg}$ and exposed to $4{ }^{\circ} \mathrm{C}$ for $24 \mathrm{~h}$. Control SX rats were implanted with pellets devoid of CGP-12177 or NE. Probability values: a versus $b$, $P<0.01$ (ANOVA and Duncan's test).

particular stimulatory action of $\mathrm{NE}(21,22)$. The stimulation of beta-1- and beta-2-adrenoreceptors activates adenylate cyclase but does not lead to a thermogenic response in rat BAT, as measured by oxygen consumption (8). On the other hand, stimulation of the beta-3-receptor activates thermogenesis, which led to the suggestion that this receptor was predominantly or solely the adrenergic receptor coupled to BAT thermogenesis (8).

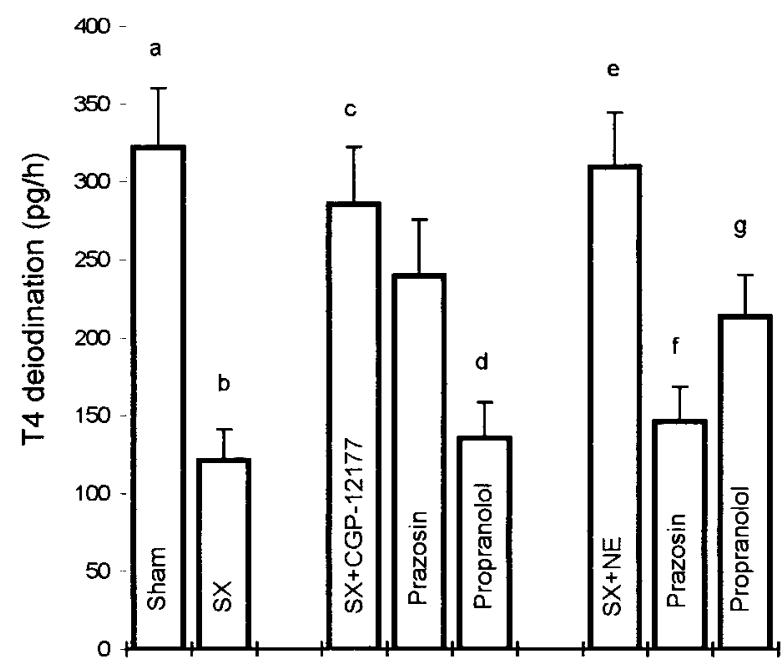

Figure 2 T4 deiodination in SX BAT $4 \mathrm{~h}$ after the injection of CGP-12177 or NE $1 \mathrm{mg} / \mathrm{kg} \mathrm{BW}$ i.p. and a $4 \mathrm{~h}$ exposure to $4^{\circ} \mathrm{C}$. Prazosin $(0.4 \mathrm{mg} / 100 \mathrm{~g} \mathrm{BW})$ or propranolol $(0.5 \mathrm{mg} / 100 \mathrm{~g} \mathrm{BW})$ was injected i.p. $15 \mathrm{~min}$ before and $2 \mathrm{~h}$ after the administration of the adrenergic agents. Results are means \pm S.D. Five animals per group were studied. Probability values: a versus $b, c$ versus $d$ and $e$ versus f, $P<0.01$; e versus g, $P<0.02$ (ANOVA and Duncan's test).
Early studies performed in vivo by Silva \& Larsen (7, 18) had shown that pretreatment of rats with the specific alpha-1-receptor antagonist prazosin inhibited NE- or cold-stimulated increases in BAT deiodinase. These findings led to the conclusion that BAT 5'deiodinase activity was predominantly mediated via alpha-1-adrenoreceptors, with a minor participation of beta-receptors. Further studies by Raasmaja \& Larsen (9) performed in cultured brown adipocytes showed a complex interrelationship between alpha-1- and betareceptors, suggesting a synergistic action between these two types of receptors. The present findings indicate that the in vivo administration of CGP-12177 stimulated 5'deiodination with a time-course comparable to that of NE. The pellets used in this study released the adrenergic compounds steadily during a period of approximately $72 \mathrm{~h}$, with a peak between 24 and $48 \mathrm{~h}$ (23). When CGP-12177 was administered by a single i.p. injection, it restored deiodination to within normal values, although slightly lower than the effect of NE. The $4 \mathrm{~h}$ effects of CGP-12177 were abolished by propranolol but not by prazosin, thus confirming that beta-receptors were mostly or solely involved in the in vivo activation of $5^{\prime}$-DII. These results correlate with those obtained in isolated brown adipocytes in vitro by Pavelka et al. (24) and Hernandez \& Obregón (25). In rats injected with $\mathrm{NE}$, however, prazosin - and to a lesser extent propranolol - blocked the NE effect, thereby suggesting that the natural agonist activated 5'-DII in vivo via alpha-1-receptors and to a lesser extent through beta-receptors. A selective, high affinity beta-3receptor blocker which would facilitate the analysis of the results has not yet been identified. We used propranolol, whose affinity for beta-3-receptors is far below (26) its affinity for beta-1 and beta-2-receptors $(11,21)$. Based on the sharp inhibition of CGP-12177 by propranolol and the fact that this adrenergic agonist interacts with receptors other than those with which NE interacts (27), one cannot rule out that beta-receptor subtypes other than beta-3 may have participated in the BAT response to CGP-12177. NE was slightly more efficient than the synthetic agonist in promoting $5^{\prime}$-DII activity. Other parameters of BAT thermogenesis, such as oxygen consumption (11) and GDP binding to BAT mitochondrial proteins (A Zaninovich) also showed that NE was moderately more effective. This could be the result of a complex mechanism for the in vivo activation of $5^{\prime}$-DII, which would involve NE and more than one type of adrenergic receptor. Zhao et al. (28) showed that both beta-3- and alpha-1-receptors mediated the activation of BAT oxygen consumption. The alpha-1receptor appeared to potentiate the ability of cAMP to stimulate thermogenesis synergistically with the beta-3receptor. A synergism between beta- and alpha-1receptors in the stimulation of $5^{\prime}$-DII activity was observed in isolated adipocytes (9) although other in vitro studies $(24,25)$ failed to detect a role for alpha-1-receptors, perhaps due to different cell culture 
conditions. The present data indicate that the in vivo administration of CGP-12177 can activate BAT 5'-DII via beta-receptors without a significant participation of alpha-1-receptors. It should be kept in mind, however, that this pathway may differ from that used by the natural agonist under physiological conditions.

\section{Acknowledgements}

This work was supported by grants 5326 from der Österreichischen Nationalbank, Vienna, Austria and PIP 4002/96 and PICT/97 from the National Research Council of Argentina.

\section{References}

1 Bianco AC \& Silva JE. Intracellular conversion of thyroxine to triiodothyronine is required for the optimal thermogenic function of brown adipose tissue. Journal of Clinical Investigation 198779 295-300.

2 Bianco AC \& Silva JE. Optimal response of key enzymes and uncoupling proteins to cold in brown adipose tissue depends on local triiodothyronine generation. American Journal of Physiology (Endocrinology and Metabolism 16) 1987253 E255-E263.

3 Silva JE. Full expression of uncoupling protein gene requires the concurrence of norepinephrine and triiodothyronine. Molecular Endocrinology 19882 706-713.

4 Rothwell NJ \& Stock MJ. Brown adipose tissue. In Recent Advances in Physiology, pp 349-384. Ed. PF Backer. Edinburgh: ChurchillLivingstone, 1984

5 Nichols DG \& Locke RM. Thermogenic mechanisms in brown fat. Physiological Reviews 198464 1-64.

6 Himms-Hagen J. Brown adipose tissue thermogenesis. FASEB Journal 19904 2890-2898.

7 Silva JE \& Larsen PR. Adrenergic activation of triiodothyronine production in brown adipose tissue. Nature $1983305712-713$.

8 Zhao J, Unelius L, Bengtsson T, Cannon B \& Nedergaard J. Coexisting $\beta$-adrenoreceptor subtypes: significance for thermogenic process in brown fat cells. American Journal of Physiology (Cell Physiology 36) 1994267 C969-C979.

9 Raasmaja A \& Larsen PR. $\alpha_{1}$ - and $\beta$-adrenergic agents cause synergistic stimulation of the iodothyronine deiodinase in rat brown adipocytes. Endocrinology 1989125 2502-2509.

10 Muzzin P, Revelli JP, Kuhne F, Gocayne JD, McCombie WR, Venter IC et al. An adipose tissue specific $\beta$-adrenergic receptor. Molecular cloning and down regulation in obesity. Journal of Biological Chemistry 1991266 24053-24058.

11 Scarpace PJ, Matheny M \& Borst SE. Thermogenesis and mitochondrial GDP binding with age in response to the novel agonist CGP-12177A. American Journal of Physiology (Endocrinology and Metabolism 25) 1992262 E185-E190.

12 Cageao LF, Noli MI, Mignone IR, Farber M, Ricci CR, Hagmüller K et al. Relative roles of the thyroid hormones and noradrenaline on the thermogenic activity of brown adipose tissue in the rat. Journal of Endocrinology 1995145 579-584.

13 Korsatko W, Porta S, Sadjak A \& Supanz S. Implantation von Adrenalin-retard Tabletten zur Langzeituntersuchung in Ratten. Pharmazie 198237 565-568.
14 Leonard JL, Mellen SA \& Larsen PR. Thyroxine 5'-deiodinase activity in brown adipose tissue. Endocrinology $19831121153-$ 1155.

15 Paier B, Hagmüller K, Noli MI, Gonzalez Pondal M, Stiegler C \& Zaninovich AA. Changes induced by cadmium administration on thyroxine deiodination and sulfhydryl groups in rat liver. Journal of Endocrinology 1993138 219-224.

16 Pavia MA Jr, Paier B, Noli MI, Hagmüller K \& Zaninovich AA. Evidence suggesting that cadmium induces a non-thyroidal illness syndrome in the rat. Journal of Endocrinology 1997154 113-117.

17 Porta S, Epple R, Kvetnansky R, Leitner G, Emsenhuber W \& Radkohl W. Temporary increase of plasma epinephrine affects stress response 24 h later. Physiology and Behavior 199538 223228.

18 Silva JE \& Larsen PR. Hormonal regulation of iodothyronine 5'deiodinase in rat brown adipose tissue. American Journal of Physiology (Endocrinology and Metabolism 14) 1986251 E639E646.

19 Esbenshade TA, Han C, Theroux TL, Granneman JG \& Minneman KP. Coexisting $\beta 1$ - and atypical $\beta$-adrenergic receptors cause redundant increase in cyclic AMP in human neuroblastoma cells. Molecular Pharmacology 199242 753-759.

20 Galitzky J, Reverte M, Portillo M, Carpéné C, Lafontan M \& Berlan M. Coexistence of $\beta 1$-, $\beta 2$-, and $\beta 3$-adrenoceptors in dog fat cells and their differential activation by catecholamines. American Journal of Physiology (Endocrinology and Metabolism 27) 1993264 E403-E412.

21 Rothwell NM, Stock M \& Sudera C. $\beta$-Adrenoreceptors in brown adipose tissue: proportion of $\beta 1$ - and $\beta 2$-subtypes. American Journal of Physiology (Endocrinology and Metabolism 11) 1985248 E397-E402.

22 Muzzin P, Colomb C, Giacobino JP, Venter JC \& Fraser CM. Biochemical characterization of brown adipose tissue $\beta$-adrenergic receptor. Journal of Receptors Research 19888 713-729.

23 Porta S, Sadjak A, Supanz S, Pürstner P, Korsatko W \& Wabnegg B. Peculiar long-term effects of catecholamines and their blockers in rats on insulin, glucose and pancreas. Experimental Pathology $198426241-245$.

24 Pavelka S, Hermanska J, Baudysova M \& Houstek J. Adrenergic control of induction of type II iodothyronine $5^{\prime}$-deiodinase activity in cultured mouse brown adipocytes. Biochemical Journal 1993 292 303-308.

25 Hernandez A \& Obregón J. T3 potentiates the adrenergic stimulation of type II $5^{\prime}$-deiodinase activity in cultured rat brown adipocytes. American Journal of Physiology (Endocrinology and Metabolism 34) 1996271 E5-E23.

26 Arch JRS. The brown adipocytes $\beta_{3}$-adrenoreceptor. Proceedings of the Nutrition Society 198948 215-223.

27 Granneman JG \& Whitty CJ. CGP-12177 a modulates brown fat adenylate cyclase activity by interacting with two distinct receptor sites. Journal of Pharmacology and Experimental Therapeutics $1991256421-425$.

28 Zhao J, Cannon B \& Nedergaard J. $\alpha_{1}$-Adrenergic stimulation potentiates the thermogenic action of $\beta_{3}$-adrenoreceptor-generated cAMP in brown fat cells. Journal of Biological Chemistry 1997 $27232847-32856$.

Received 11 February 2000

Accepted 20 April 2000 